\title{
Designing an Arduino-based Automatic Cocoa Fermentation Tool
}

\author{
Balkhaya $^{1)^{*}}$, Dirja Nur Ilham ${ }^{2)}$, Rudi Arif Candra ${ }^{3)}$, Hasbaini $^{4)}$, Fera Anugreni ${ }^{5)}$ \\ 122)344)5) Politeknik Aceh Selatan, Indonesia \\ ${ }^{1}$ balkhaya@poltas.ac.id, ${ }^{2}$ dirja@ poltas.ac.id, ${ }^{3)}$ rudi_candra@ poltas.ac.id, ${ }^{4}$ hasbaini@ poltas.ac.id, \\ ${ }^{5)}$ anugreni@poltas.ac.id
}

Submitted : Sept 4, 2020 | Accepted : Oct 8, 2020 | Published : Oct 8, 2020

\begin{abstract}
Automatic cocoa fermentation design is expected to facilitate the work of cocoa farmers during the process of reversing and stirring cocoa fermentation based on the right temperature. Fermentation process is of course done in a box or sack so that chocolate quickly produces heat and is cemented. However, in certain conditions, especially when in sacks there are often obstacles in the stirring process. Often the fermented chocolate experiences weathering or moldyness due to the uneven reversal that causes chocolate to clot, causing weathering or moldiness and produce an unpleasant odor and unattractive color on the cocoa beans. To overcome this problem a tool that automatically can turn or stir the cocoa beans evenly. This device is controlled by Arduino Uno R3 with a sensor that is an LM35 temperature sensor and has an LCD output and DC motor. This tool uses Relay to adjust the delay when driving a DC motor. The working principle of this tool, when the LM35 temperature sensor receives heat conditions on the cocoa beans, the LCD will display the condition of the temperature while the relay will instruct the DC motor to move the Cocoa Fermentation rail rotating left or right. The purpose of making this tool is to create a tool that can help alleviate the work of cocoa farmers in cocoa bean stirring activities at the time of cocoa bean fermentation controlled by Arduino. From the results of the tests carried out, the tool is able to read both hot and cold temperature conditions, and the LM35 sensor can work well in detecting temperature changes from $35^{\circ} \mathrm{C}$ to $40^{\circ} \mathrm{C}$ or vice versa.
\end{abstract}

Keywords: Microcontroler, Arduino Uno, LM35, Relay, Fermentation

\section{INTRODUCTION}

Indonesia is one of the main cocoa supplier countries in the world after Ivory Coast (38.3\%) and Ghana (20.2\%) with a percentage of $13.6 \%$ (Directorate General of Plantation, 2013). Thus, the cocoa commodity plays an important role in the national economy and has become one of the national mainstay commodities after rubber and palm oil.

Until now, approximately $90 \%$ of farmers sell cocoa in the form of beans for export, but the quality of the cocoa beans is still low because they are not fermented, have low moisture content, are attacked by fungi, mixed with dirt or other foreign objects. This has an impact on destination countries for cocoa exports, especially in the United States. Indonesian cocoa is subject to automatic detention and automatic discount in the United States so that its competitiveness is lower than cocoa produced by other countries.

Previous research conducted "Cocoa Postharvest Handling" to determine the handling of cocoa such as the process of harvesting, sorting, fermentation, and processing(Amaran, Iradhatullah Rahim, 2018). another study also conducted "Development of Prototype of Cocoa Beans Fermentation Containers"(Eka, 2015). Research on automatic cocoa fermentation tools will use the Arduino Uno microcontroller as an automatic controller because it has features and the number of I / O that match the system requirements(Darmawan, 2019).

Furthermore, several studies that use the LM35 temperature sensor and arduino-based research include automatic fan research using temperature sensors and infrared by microcontroller control by(Mareta, Mutmainah, P, A, \& F, 2019). utilization of the LM35 temperature sensor in the sea water temperature control system on a small scale by(Indriani, Johan, Witanto, \& Hendra, 2014). The realization of the LM35DZ temperature sensor as a microcontroller based fluid flow velocity sensor(Nopilawati \& Pauzi, 2016). Utilization of temperature sensors, gas sensors and motion sensors as anti-fire safety based on Arduino by(Shofa, Amalia, Santoso, Ismiati, \& Bakti, 2018). Research on heart rate monitoring and stimulation(Ilham, Hardisal, Balkhaya, Candra, \& Sipahutar, 2019). Home security uses arduino based on the internet of things by(Rozi, Amnur, Fitriani, \& Primawati, 2018). 
Research on light control using social media(Candra, Ilham, Hardisal, \& Sriwahyuni, 2019). Arduino-based automatic water machine control using a smartphone by(Lubis et al., 2019). Control device that utilizes internet technology by using social media telegram applications (Candra \& Ilham, 2019). The design of an automatic paddy gate controller based on the Arduino Uno Microcontroller (Dharma, Tansa, \& Nasibu, 2019). Utilization of Arduino Uno for automatic drying by(Murakabiman, Wahyu, \& Pratama, 2019).

From some of the studies above, this research will make an automatic cocoa fermentation device using an arduino-based LM35 temperature sensor.

\section{LITERATURE REVIEW}

Fermentation is a process of producing a product with microbes as processing organisms. One of the important steps in the post-harvest handling of cocoa is the fermentation process. Fermentation of cocoa beans aims to facilitate the release of mucus from the surface of the bean shell and form a distinctive chocolate flavor and reduce the bitter and chewy taste in cocoa beans so that they produce beans with good quality and aroma, as well as a bright and clean brown color. In cocoa fermentation, several factors are needed to be considered in order to produce the best cocoa beans, namely temperature, cocoa weight, and the right time for stirring and moving. This automatic cocoa fermentation device works based on the basic principles of conventional cocoa fermentation tools previously in conventional cocoa fermentation tools. This is done by using sacks that have small holes to allow oxygen to enter, the sacks are not filled completely, left $5 \mathrm{~cm}$ from the top and the top surface is covered with leaves. banana which aims to retain heat and prevent the surface of the seeds from drying out. This fermentation process lasts for 2-6 days with 3-5 times turning and stirring by removing the other sacks (Nuraini, 2017).

While the automatic cocoa fermentation tool that will be made regulates the motor rotation according to the temperature value in the cocoa fermentation reversal process which functions as a stirrer like conventional fermentation tools with a short time in the fermentation process and produces an even temperature.

\section{METHOD}

The tools and materials used for the manufacture of an Arduino-based automatic cocoa fermentation device consist of hardware and software including:

\section{Hardware}

Requirements The devices used in the design of an automatic cocoa fermentation device include:

Table 1

Hardware Specifications

\begin{tabular}{|c|c|c|}
\hline No & Name & Function \\
\hline 1 & Laptop windows 7 & $\begin{array}{l}\text { As a place to run applications in automatic fermentation } \\
\text { design. }\end{array}$ \\
\hline 2 & Arduino uno R3 & $\begin{array}{l}\text { As a controller of the components in automatic } \\
\text { fermentation. }\end{array}$ \\
\hline 3 & Motor DC & $\begin{array}{l}\text { Driving the fermentation radius so that it rotates or remains } \\
\text { in accordance with temperature conditions. }\end{array}$ \\
\hline 4 & LCD16x2 Backlight & Displays the temperature conditions accepted by sensor. \\
\hline 5 & Jumper Cables & As a liaison for one component with other components. \\
\hline 6 & Sensor $\operatorname{lm} 35$ & As a detector for hot and not hot temperatures. \\
\hline 7 & Breadboard & $\begin{array}{l}\text { Place all the components inside Automatic clothesline } \\
\text { design. }\end{array}$ \\
\hline
\end{tabular}

\section{Software}

The software used in designing a microcontroller based out infusion warning is:

Table 2

Design Software

\begin{tabular}{cll}
\hline No & \multicolumn{1}{c}{ Name } & \multicolumn{1}{c}{ Function } \\
\hline 1 & Arduino IDE & Used to upload a low infusion warning program to the \\
& & Arduino board. \\
2 & Proteus & Used to simulate circuits \\
3 & Fritzing & Used to design circuit schematics and electronics \\
4 & Microsoft Visio & Used for designing drawings, schematics \\
5 & MatLab & Software to Analyze Research Results \\
\hline
\end{tabular}

Work Procedure 


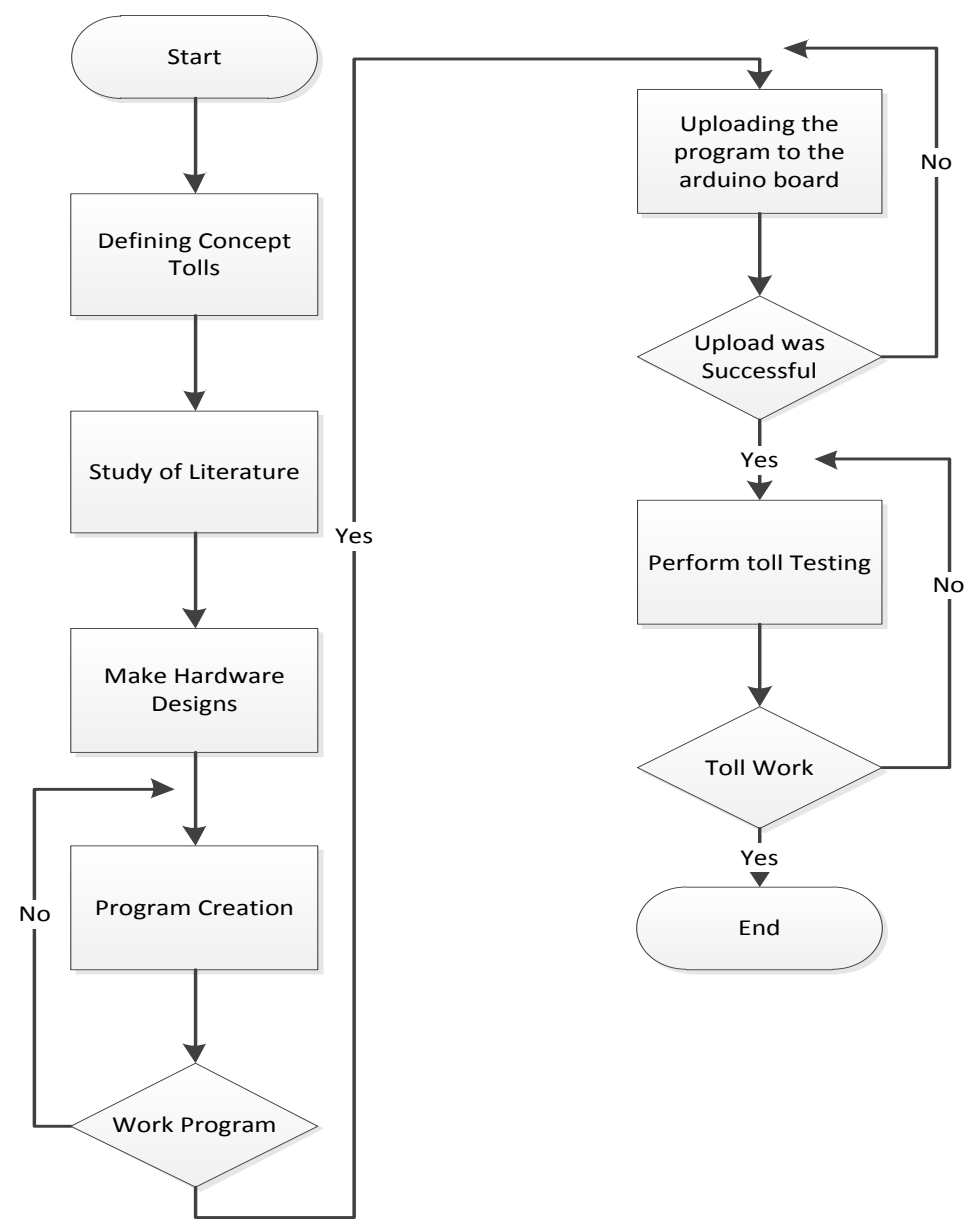

Figure 1. Work procedure

The work process starts from determining the concept of the tool, after that looking for literature studies, then proceed to hardware design, proceed to making program listings after that the program is uploaded to the Arduino device after it is successful, then testing the tool according to what was planned or not, then continue to the final settlement.

\section{System Design}

This design was made to simplify the process of designing an automatic fermentation device using an arduinobased LM35 temperature sensor. The series of automatic fermentation equipment consists of four parts, namely the process part, the control part, the display part and the actuator part. As shown in Figure 2.

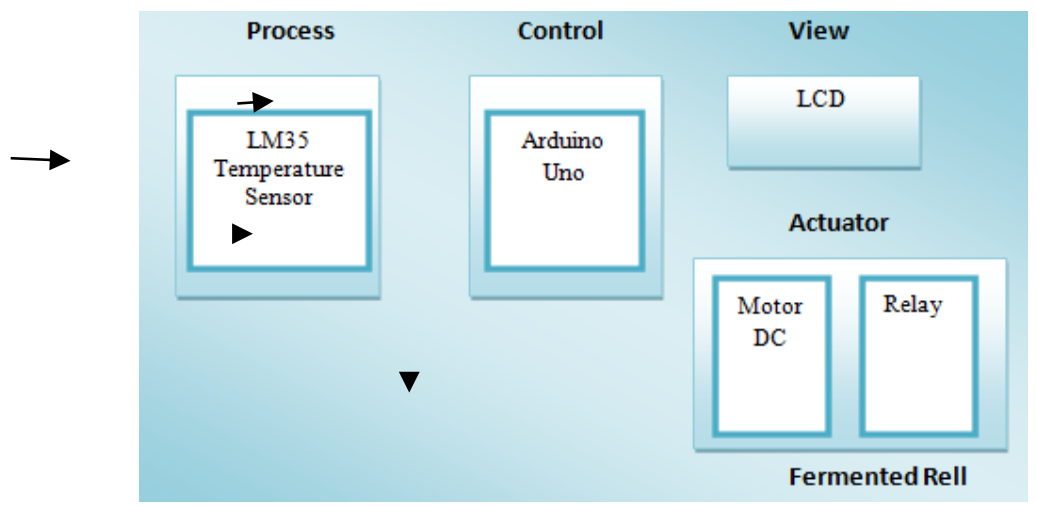

Figure 2. System Design

From Figure 2, it can be seen that there are four parts of the circuit, namely the Process section, this section consists of the LM35 sensor which detects the temperature rising or falling. 
The control part, this automatic fermentation control system uses Arduino which functions to receive the process from the LM35 sensor then gives commands to the DC motor which is an actuator to turn or stir the Cocoa beans.

The display part consists of an LCD (Liquid Crystal Display) which is used to display the temperature conditions received by the LM35 temperature sensor.

The actuator part, the actuator part or the driving part of the automatic cocoa fermentation rail consists of a relay and a DC motor. Relays are used to drive DC motors, because DC motors cannot be controlled directly by Arduino.

1. Working Principles of Tools

The following is a flowchart of a design for how the automatic cocoa fermentation device will work. As in figure 3.

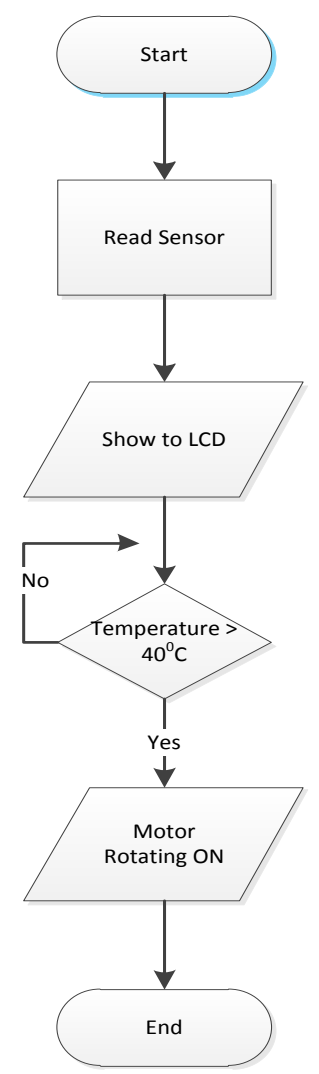

Figure 3. The working principle of the tool

From Figure 3, it can be seen that when the system starts, the sensor will read the temperature state of the cocoa beans being fermented, then the value of the temperature will be displayed on the LCD. When the temperature rises $>40^{\circ} \mathrm{C}$, if YES the motor will rotate automatically, otherwise the motor will not rotate or stop automatically.

\section{Range of tools}

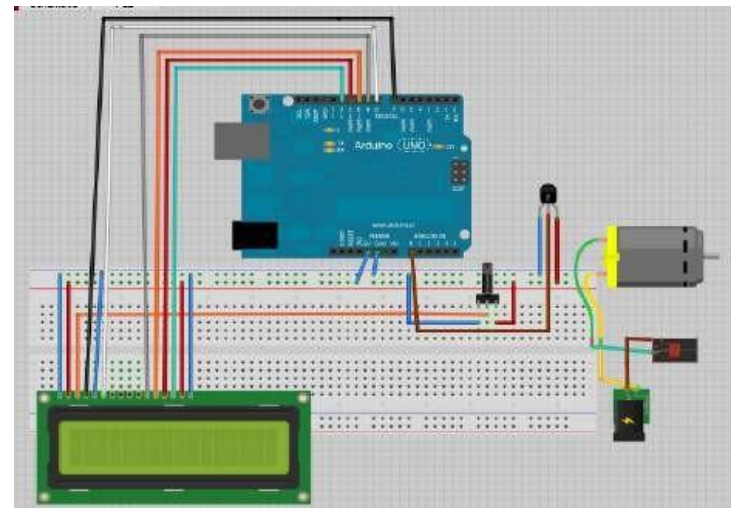

Figure 4. Schematic of the Tool

The IN pin on the relay is connected to (-) on the breadboard, the GND pin on the relay is connected to Pin 4 on the Arduino, the VCC pin on the relay is connected to $(+)$ on the breadboard. Then $(-)$ the adapter is connected to 
the (-) conveyor. (+) on the adapter is connected to pin NO on the relay. (+) on the conveyor is connected to the COM pin on the Relay.

\section{RESULT}

The automatic fermentation tool works based on the process of the temperature sensor, where the process of the sensor will be the input for Arduino as the main controller to give commands to the LCD to display the temperature conditions read by the sensor, and to give commands to the Relay.

Relays are used to drive the dc motor rotating right or left based on the input of temperature. In addition, the adapter is used to control the rotation speed of a DC motor. When the motor rotates right or left, the fingers will move in the direction of the DC motor rotation.

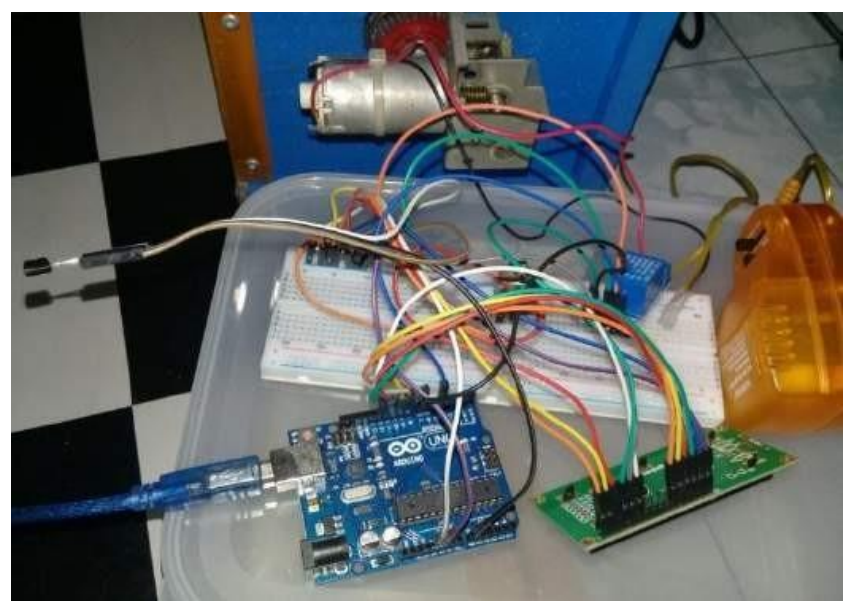

\section{Testing Procedure}

Figure 5. Overall Toolkit

- Overall Tool Testing

To operate an automatic Cocoa Fermentation tool using the LM35 sensor is as follows:

a) The first thing to do is to first assemble all these tools together and ready to operate.

b) After all the tools are connected, turn on the Adapter which is the main voltage source. After the Adapter turns on, the whole circuit will be active, and at that time the sensor will detect the current temperature state.

c) When the LM35 sensor detects a hot temperature, which means the temperature is high, the motor will move the fermentation radius to rotate automatically.

d) When the LM35 sensor detects a cold temperature, which means the temperature is low, the motor will not move the fermentation radius or the motor will stop automatically.

\section{Test result}

\section{- Sensor}

In testing the sensor aims to determine the relationship and temperature response in the fermentation process of cocoa beans to the fermentation time of cocoa beans in the appliance.

Table 3

Results of temperature testing without load on cocoa beans

\begin{tabular}{ccc}
\hline Testing & Time & Temperature \\
\hline 1 & 4 & $30^{\circ} \mathrm{C}$ \\
2 & 8 & $35^{\circ} \mathrm{C}$ \\
3 & 12 & $39^{\circ} \mathrm{C}$ \\
4 & 20 & $32^{\circ} \mathrm{C}$ \\
5 & 24 & $41^{\circ} \mathrm{C}$ \\
6 & 28 & $49^{\circ} \mathrm{C}$ \\
7 & 32 & $45^{\circ} \mathrm{C}$ \\
\hline
\end{tabular}

6.

From Table 3, a graph of the results of motor testing with no load of cocoa beans is obtained as shown in Figure

Graph of Changes in Fermentation Temperature for 2 Days Without Cocoa Beans Burden 


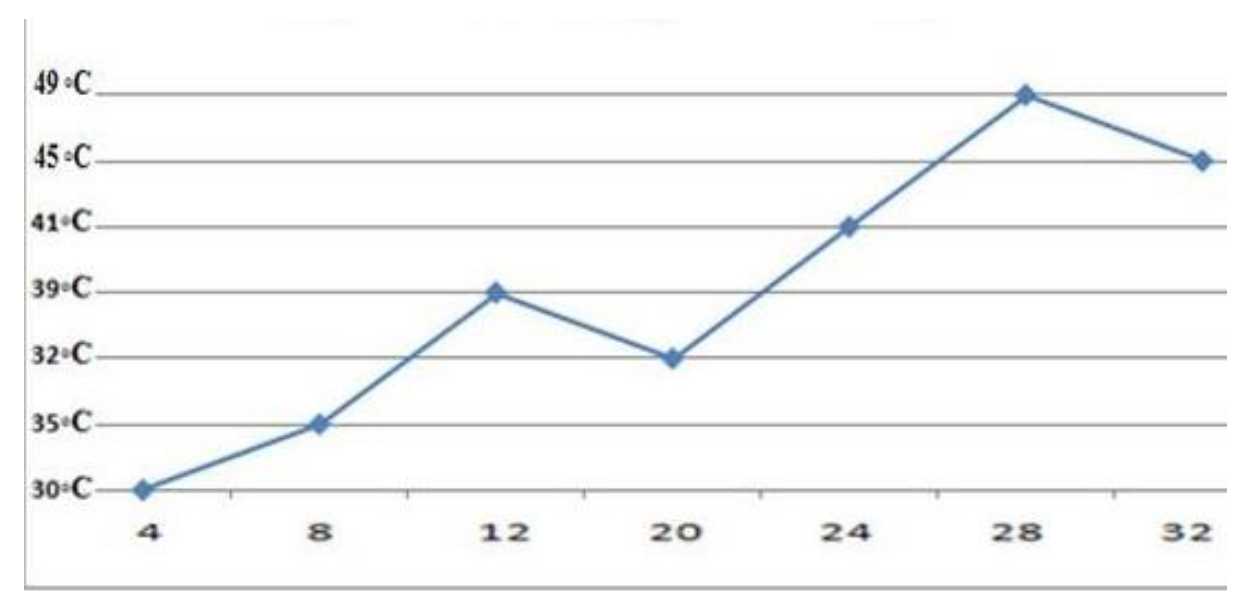

Figure 6. Graph of Changes in Temperature of Fermentation Tool without the burden of cocoa beans

In Table 3 and Figure 6 it is known that the relay starts $\mathrm{ON}$ at 24 hours after the temperature value reaches $41^{\circ} \mathrm{C}$ seen from the Table and Graph that the temperature increase has an abnormal increase in the test without the load of cocoa beans.

The table of the results of the fermentation temperature test using the load of cocoa beans on the cocoa fermentation tool is shown in Table 4.

Table 4

The results of the $\mathrm{T}$ temperature test with a load of $3 \mathrm{~kg}$ of cocoa beans

\begin{tabular}{|ccc|}
\hline Testing & Time & Temperature \\
\hline 1 & 4 & $32^{0} \mathrm{C}$ \\
2 & 8 & $34^{0} \mathrm{C}$ \\
3 & 12 & $37^{0} \mathrm{C}$ \\
4 & 16 & $40^{0} \mathrm{C}$ \\
5 & 20 & $45^{\circ} \mathrm{C}$ \\
6 & 24 & $46^{\circ} \mathrm{C}$ \\
7 & 28 & $46^{\circ} \mathrm{C}$ \\
\hline
\end{tabular}

From table 4, it is obtained a graph of the results of fermentation temperature testing using a $3 \mathrm{~kg}$ load of cocoa beans on the cocoa bean fermentation tool which is shown in Figure 7.

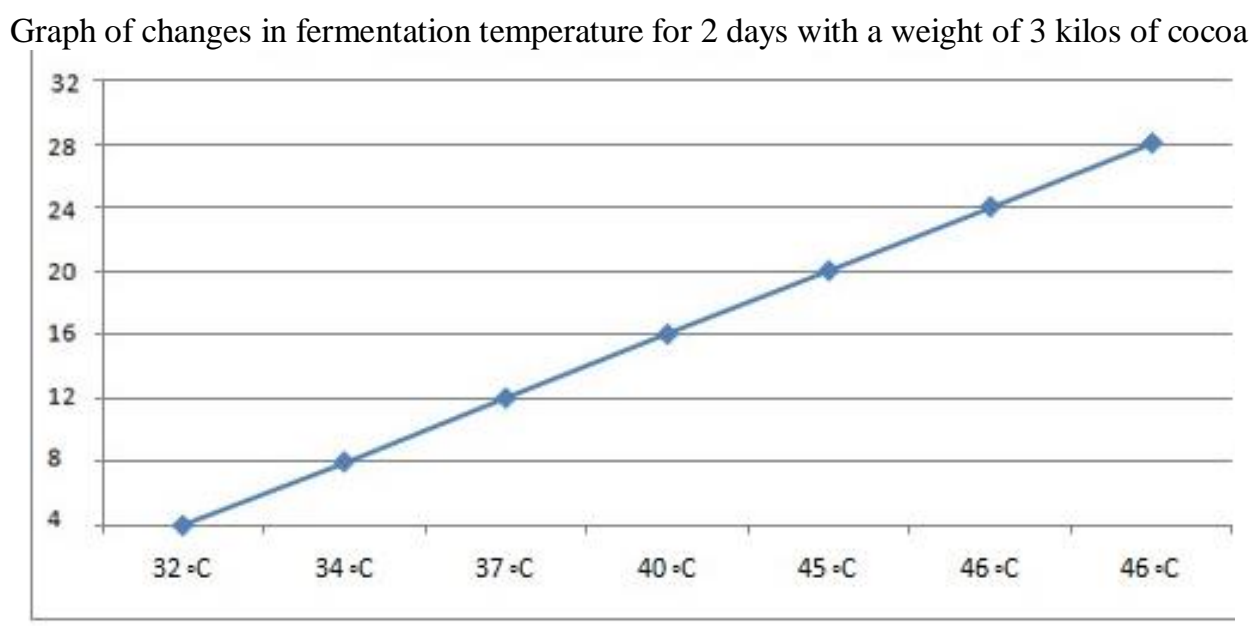

Figure 7. Graph of LM35 Sensor Relationship with temperature using a load of 3 kilo grams of cocoa beans

In Table 4 and Figure 7 it is known that the temperature value starts to appear $40^{\circ} \mathrm{C}$ at 16 hours after the temperature value reaches $40^{\circ} \mathrm{C}$ until it increases in testing with a load of $3 \mathrm{~kg}$ cocoa beans. 
After conducting tests with a load of $3 \mathrm{~kg}$ cocoa beans on this fermentation tool, it is only limited to measuring the temperature for heavy loads of cocoa beans up to $3 \mathrm{~kg}$, it can be concluded that the sensor value on the load of $3 \mathrm{~kg}$ cocoa beans is $40^{\circ} \mathrm{C}$ or the relay will be on when the temperature is $40^{\circ} \mathrm{C}$ at 16 hours, while the sensor value without using a load of cocoa beans temperature $40^{\circ} \mathrm{C}$ will appear at 24 hours.

From the results of the Table and Graph above, it can be seen that the difference in yields of cocoa beans which are fermented completely and which are not perfect.

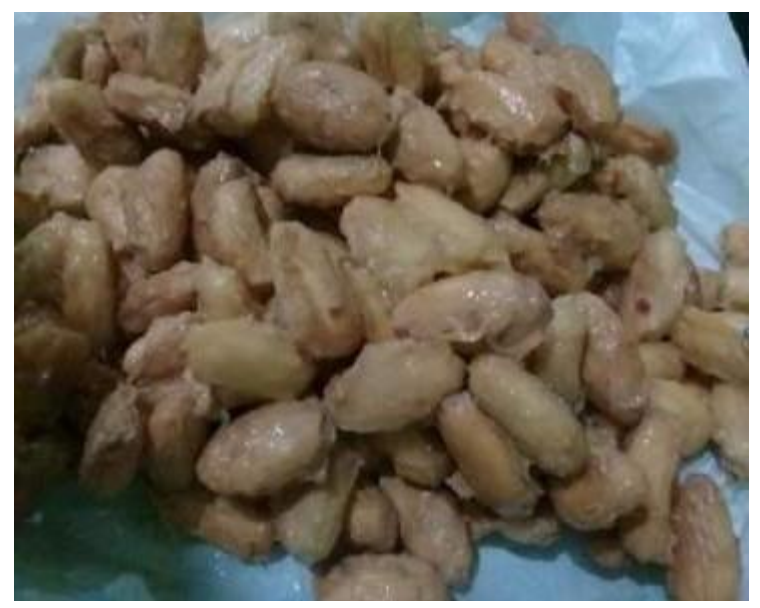

Figure 8. Perfect fermentation of cocoa

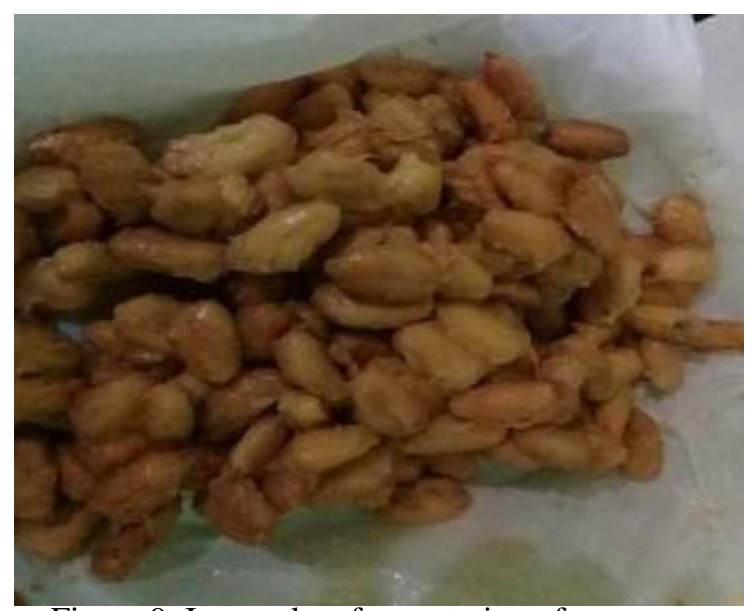

Figure 9. Incomplete fermentation of cocoa

To get a high selling price, the cocoa beans that have been harvested must be processed immediately. The correct post-harvest processing of cocoa beans is carried out in steps that are able to maintain the quality of the beans to remain optimal. The post-harvest processing stages of cocoa are fermented beans which produce a purple brown color.

\section{DISCUSSIONS}

From testing the temperature of the permentation room without using cocoa beans, the relay will turn on at 24 hours when the temperature reaches $41 \mathrm{C}$ and the temperature increase also becomes abnormal in the test without cocoa beans, while in the room temperature test the permenter with a bean load of 3 kilo grams of cocoa is a temperature reach 40C within 16 hours. and it can be concluded that the room temperature of the new kakau fermenter will be stable if the load of cocoa seeds is inserted in it.

\section{CONCLUSION}

After designing and testing the automatic cocoa fermentation tool, it can be concluded that the successfully completed tool is able to read the temperature, both in hot and cold conditions and the use of the LM35 sensor can work well, so that in the application of this tool the LM35 sensor can detect changes temperature (from $35^{\circ} \mathrm{C}$ to $40^{\circ} \mathrm{C}$ or vice versa). 


\section{REFERENCES}

Amaran, Iradhatullah Rahim, D. (2018). Perancangan Pasca Panen Kakao. Prossiding Seminar Nasional, 1(April), 71-77.

Candra, R. A., \& Ilham, D. N. (2019). Analisis Efisiensi Energi pada Aplikasi Media Sosial Menggunakan Perangkat Komunikasi Bergerak. 9, 125-131.

Candra, R. A., Ilham, D. N., Hardisal, H., \& Sriwahyuni, S. (2019). Light Control Design by Using Social Media Telegram Applications Based on Internet Of Things (IOT). SinkrOn, 3(2), 200. https://doi.org/10.33395/sinkron.v3i2.10094

Darmawan, D. (2019). Rancang Bangun Lemari Pengering Biji Kakao Berbasis Mikrokontroler Arduino Uno 328P. Journal of Chemical Information and Modeling, 53(9), 1689-1699. https://doi.org/10.1017/CBO9781107415324.004

Dharma, I. P. L., Tansa, S., \& Nasibu, I. Z. (2019). Perancangan Alat Pengendali Pintu Air Sawah Otomatis dengan SIM8001 Berbasis Mikrokontroler Arduino Uno. Jurnal Teknik, 17(1), 40-56. https://doi.org/10.37031/jt.v17i1.25

Eka, R. (2015). Pengembangan Prototipe Wadah Fermentasi Biji Kakao ( Theobroma cocoa L .) dengan Agitator Otomatis Berbasis Mikrokontroller. (September), 2-3.

Ilham, D. N., Hardisal, H., Balkhaya, B., Candra, R. A., \& Sipahutar, E. (2019). Heart Rate Monitoring and Stimulation with the Internet of Thing-Based (IoT) Alquran Recitation. SinkrOn, 4(1), 221. https://doi.org/10.33395/sinkron.v4i1.10392

Indriani, A., Johan, J., Witanto, Y., \& Hendra, H. (2014). Pemanfaatan Sensor Suhu LM 35 Berbasis Microcontroller ATmega 8535 Pada Sistem Pengontrolan Temperatur Air Laut Skala Kecil. Rekayasa Mesin, 5(2), 183-192. https://doi.org/10.21776/ub.jrm

Lubis, Z., Lungguk, A., Saputra, N., Winata, S., Annisa, A., Muhazzir, B., ... Sri, W. (2019). Kontrol Mesin Air Otomatis Berbasis Arduino Dengan Smartphone. Cetak) Buletin Utama Teknik, 14(3), 1410-4520.

Mareta, R., Mutmainah, S., P, N. Y., A, M. R., \& F, R. A. (2019). Kipas Angin Otomatis Menggunakan Sensor Suhu Dan Sensor Kipas Angin Otomatis Menggunakan Sensor Suhu Dan Sensor Infrared Dengan Mikrokontroler Atmega32. (July), 0-3. https://doi.org/10.13140/RG.2.2.24545.86886

Murakabiman, Z., Wahyu, M., \& Pratama, C. (2019). Pemanfaatan Arduino Uno Untuk Jemuran Pakaian Otomatis. (May), 0-10. https://doi.org/10.13140/RG.2.2.33146.34246

Nopilawati, D., \& Pauzi, G. A. (2016). Realiasasi Sensor Temperatur LM35DZ Sebagai Sensor Kecepatan Aliran Fluida Berbasis Mikrokontroler ATMega32 dengan Media Penyimpan Data Micro Secure Digital ( Micro SD ). Jurnal Teori Dan Aplikasi Fisika, 04(02), 161-166.

Nuraini, L. (2017). Rotary untuk Meningkatkan Mutu Biji Buah Kakao Desa Sumber Agung Kabupaten Banyuwangi. 10(November), 72-76.

Rozi, F., Amnur, H., Fitriani, F., \& Primawati, P. (2018). Home Security Menggunakan Arduino Berbasis Internet Of Things. INVOTEK: Jurnal Inovasi Vokasional Dan Teknologi, 18(2), 17-24. https://doi.org/10.24036/invotek.v18i2.287

Shofa, A. D., Amalia, D., Santoso, E., Ismiati, E., \& Bakti, V. K. (2018). Pemanfaatan Sensor Suhu, Sensor Gas Dan Sensor Gerak Sebagai Pengaman Anti Kebakaran Berbasis Arduino. 17(2), 65-71. 